http://dx.doi.org/10.4314/jae.v15i1.13

\title{
Assessment of Constraints to Cassava Value-Added Enterprises in Kwara State, Nigeria
}

Achem, B.A

National Centre for Agricultural Mechanization (NCAM), P.M.B 1525, llorin, Kwara State, Nigeria

E-mail: achemb2000@yahoo.com; mobile phone: +234(0)8056147244

\begin{abstract}
The study examined constraints to cassava processing in Kwara State, Nigeria. A 2-stage sampling technique was used to randomly select 160 cassava processors in the 16 Local Government Areas (LGAs) of the state from the list of registered processors obtained from Kwara Agricultural Development Programme (ADP). Structured interview schedule was used as instrument to elicit primary data from the respondents. The socio-economic characteristics were subjected to descriptive statistics, while the constraints were rated on a 4-point Likerttype scale. Chi-square $\left(X^{2}\right)$ was used to test the relationship between selected socio-economic characteristics and constraints to cassava processing. The result of analysis revealed that 36.3 percent of the respondents were within the age range of 41 and 50 years, majority (87\%) were women, and 55.6 percent had household sizes of between 6 and 8 members. Those without formal education constituted 40 percent, 44.4 percent had less than 10 years experience in cassava processing, while majority (68\%) sourced funds for cassava processing from personal savings. The severe constraints of cassava processing were lack of funds, high cost of processing equipment, and scarcity of cassava tubers with respective mean scores $(\bar{X})$ of $3.44,3.35$ and 3.23. The chi-square test of independence revealed that positive and significant relationship existed between socio-economic characteristics such as gender, educational status, marital status, membership of cooperative society, age of processor and experience in cassava processing at 5\% level of significance. Subsidy on cassava processing equipment, reduction of interest rates and a buy-back policy of processed cassava products by governments were recommended.
\end{abstract}

Keywords: Cassava, constraints, Kwara state and value addition. 


\section{INTRODUCTION}

Food security has remained on the front burner as a key issue being addressed by developing nations. Cassava (Manihot esculanta), variously designated as Manioc, Tapioca or Yucca has been acknowledged as one of the most popular staple crops in the African diet (Nweke et al. 2007). Its adaptability to marginal soils and erratic rainfall conditions, as well as its high-yield per unit of land makes it an ideal crop in many farming systems in Africa (Olakulehin and Ajijola, 2005). Cassava is an essential part of the diet of more than seventy (70) million Nigerians (FOA, 2003). The amount of carbohydrate contained in dry cassava roots is higher than maize or any other cereal. It supplies close to 40 percent of calorific requirements of Nigerians (Okigbo, 1980). In 1980, it was estimated that over 280 million people in Africa, Latin America and the Far East relied on cassava for most of their calorific requirements (O' Hair, 2000).

Cassava value addition refers to those agro-industrial activities which are related to the transformation of the root crop with a view to modifying its physical, chemical and rheological characteristics thereby enhancing its value. The need for cassava processing has been enumerated by several authors (Ikpi and Hahn, 1989; Ngoddy, 1977; Onabolu, 2001). Value addition facilitates transportability of processed products, reduce perishability and toxicity, enhance edibility and nutritive quality, stabilize the product for storage and guarantee higher prices for farmers. With Nigeria currently the largest producer of cassava, producing over 43 million metric tons annually (FAO 2009), the cassava transformation coming up in Nigeria will largely depend upon processing and finding additional markets for increased production. In Nigeria, cassava has been processed into food products mainly gari, lafun, fufu. However, an emerging market with tremendous capacity exists in animal feed, textiles, pharmaceuticals, confectioneries etc where highvalue cassava products like starch, high quality cassava flour (HQCF) and chips would be demanded (FAO, 2002).

The challenge to value addition and commercialization of cassava is to meet the quality requirements of elite consumers of food products, as well as the limitless opportunities that exist for utilization of processed products by industries and the international market. Nweke et al (2002) identified two broad methods of cassava processing, viz: traditional and mechanized processing. He reported that both methods had constraints including compromised product quality, reduced efficiency in labour and cost of production, and occupational/health hazards due to exposure of processors to physical and mechanical factors. Ayoade and Adeola (2009) noted that the major constraints to domestic industrialization of cassava were high cost of processing and lack of financial assistance to processors. Other constraints noted by them include ineffective link between farmers and processors, unstable agricultural policies and fluctuating power supply. The issue of government policies was corroborated by Oderemi and Awoyinfa (2008), who reported that Nigeria was on the verge of losing twenty billion Naira (N20bn) invested in the cassava commodity system between 2002 and 2008 due to reversal in government core policies. The lifting of the ban on wheat importation, 
they reported, would negatively affect the enforcement of the policy of 10 percent inclusion of high quality cassava flour (HQCF) by millers in confectioneries.

\section{Objectives of the study}

The broad objective of the study was to investigate the constraints to cassava processing in Kwara State. Specifically, the study was designed to:

(i) describe the socio-economic characteristics of cassava processors in Kwara State;

(ii) examine the constraints to cassava value adding enterprises; and

(iii) ascertain the relationship between the socio-economic characteristics of processors and constraints to cassava value adding enterprises in the study area.

\section{METHODOLOGY}

The study was conducted in Kwara State of Nigeria. The state is located in the North-Central geographical zone, and has a land mass of about 32,500 square kilometers $\left(\mathrm{km}^{2}\right)$. It is situated between the coordinates $6.50^{\circ}$ and $11.50^{\circ}$ North latitudes of the equator and longitudes $2.80^{\circ}$ and $7.50^{\circ}$ East. The average temperature varies between $27^{\circ} \mathrm{C}$ and $35^{\circ} \mathrm{C}$, while mean annual rainfall is between $1000 \mathrm{~mm}$ and $1500 \mathrm{~mm}$. The climate and vegetation supports cultivation of several crops including cassava, yam, rice, sorghum, cowpea etc. Kwara State has 16 Local Government Areas (LGAs), and is divided into 4 agricultural zones with headquarters located at Kaiama (Zone A), Patigi (Zone B), Igbaja (Zone C) and Malete (Zone D). The study was conducted state-wide, including all the Local Government Areas. They are namely: Asa, Baruten, Edu, Ekiti, Ifelodun, IlorinEast, Ilorin-South, Ilorin-West. Others include Irepodun, Isin, Kaiama, Moro, Offa, Oke-Ero, Oyun and Patigi.

\section{Sampling procedure and analytical technique}

A two stage sampling technique was adopted for the study. In the first stage, ten (10) cassava processing communities were randomly selected in each of the 16 LGAs. The second stage involved the random selection of one cassava processor from each of the communities in the 16 LGAs; making a total of 160 respondents. Kwara State Agricultural Development Project (ADP) provided the sampling frame from the list of registered cassava processors maintained in Rural Institutions Development Department (KWADP 2008).

Structured interview schedule was used as instrument to collect primary data from processors. Data captured in the interview schedule included personal and socio-economic characteristics of the processors. Ten constraints to cassava processing generated through Focused Group Discussion (FGD) were identified and captured. The dependent variable is the constraints to cassava processing, which is determined by the severity of the constraints. Independent variables are age, gender, educational status and experience in processing. Data collected was 
subjected to descriptive statistics such as mean, percentages and frequency counts. The chi-square test of independence was used to test the relationship between selected socio-economic characteristics, while the constraints to cassava processing enterprises were rated on a 4-point Likert-type scale.

\section{RESULTS AND DISCUSSION}

Table 1 indicates that most cassava processors (36.3 percent) fell within the age bracket of 41 and 50 years (with a mean of 35), while the least group of 20 years and below is 0.6 percent. This implies that most processors were in their productive stage, and should maximize their contribution to cassava processing. However, 26.9 percent of the respondents were 50 years and above. This shows that the youth are increasingly going out of cassava processing. This can be attributed to massive rural-urban migration by youth to cities in search of white collar jobs. The table revealed that both males and females engaged in cassava processing activities, but with an overwhelming presence of females, where they accounted for 87 percent. This corroborated the findings of Spencer (1976), who noted that cassava processing was more of women activity, allocating as much as 70 percent of the tasks. Also, 87.5 percent were married, while 10.60 percent were widowed. This implies that married people were more involved in cassava value addition enterprises.

Table 1 further show that most cassava processing families (55.6-percent) had household size of between 6 and 8 members, with an average of 4 . Households with more than 8 members constituted 20.6 percent. A large family size tend to suggest that more family labour could be made available for cassava processing, consequently reducing the amount spent on hired labour. 
TABLE 1: Distribution of respondents based on socio-economic characteristics

\begin{tabular}{|c|c|}
\hline Characteristics & Percentage $(n=160)$ \\
\hline \multicolumn{2}{|l|}{ Age (Years) } \\
\hline$<20$ & 0.63 \\
\hline $20-30$ & 5.00 \\
\hline $31-40$ & 31.25 \\
\hline $41-50$ & 36.25 \\
\hline$>50$ & 26.88 \\
\hline \multicolumn{2}{|l|}{ Gender } \\
\hline Female & 86.90 \\
\hline Male & 13.10 \\
\hline \multicolumn{2}{|l|}{ Marital status } \\
\hline Married & 87.50 \\
\hline Divorced & 1.90 \\
\hline Widowed & 10.60 \\
\hline \multicolumn{2}{|l|}{ Household size } \\
\hline$<3$ members & 8.10 \\
\hline 3-5 members & 15.63 \\
\hline $6-8$ members & 55.63 \\
\hline$>8$ members & 20.63 \\
\hline \multicolumn{2}{|l|}{ Educational status } \\
\hline No formal education & 40.00 \\
\hline Quranic education & 10.60 \\
\hline Adult education & 8.10 \\
\hline Primary education & 25.60 \\
\hline Secondary education & 11.20 \\
\hline Tertiary education & 4.40 \\
\hline \multicolumn{2}{|c|}{ Processing experience(Years) } \\
\hline$<10$ & 44.38 \\
\hline $11-20$ & 38.75 \\
\hline $21-30$ & 14.37 \\
\hline$>30$ & 2.50 \\
\hline \multicolumn{2}{|l|}{ Source of funds } \\
\hline Personal savings & 68.10 \\
\hline Money lenders & 10.60 \\
\hline Cooperative Society & 15.00 \\
\hline Bank Loan & 0.63 \\
\hline Others & 5.00 \\
\hline
\end{tabular}


Table 1 also indicates that cassava value addition was carried out by processors with various educational backgrounds. Majority of the processors (40 percent) had no formal education, 25.6 percent had primary education, and 10.6 percent had quranic education, while only 4.4 percent acquired tertiary education. The 40 percent level of illiteracy should be of great concern, as education is known to be a weapon of social change. The low level of literacy has implications for adoption of agricultural innovations and technical packages.

Majority of respondents (44.4 percent) had less than 10 years experience in cassava processing (Table 1). Those with between 11 and 20 years experience were 38.7 percent, while those with experience of 30 years and above were only 2.5 percent. Generally, it implies that respondents in the study area had experience in cassava processing. Table 1 also showed that 68.1 percent of cassava processors sourced their funds from personal savings, 15 percent from cooperative societies, 10.6 percent from money lenders, while only 0.6 percent obtained loan from formal credit institutions (commercial banks). Respondents interviewed attributed this to high interest rates charged by commercial banks, stringent conditionality required for accessing bank loans and general difficulty in processing bank loans.

\section{Constraints to Cassava Processing}

Table 2 shows analysis of constraints to cassava processing using a 4-point Likert-type scale. It was computed by summing the scores (frequency multiplied by magnitude of constraints) and determining the mean $(\bar{X})$ which was then ranked. The table shows that the greatest constraints to cassava value addition were lack of funds, high cost of processing equipment and scarcity of cassava roots which fell in the category of 'very severe' with mean scores of 3.44, 3.35 and 3.23 respectively. High transport cost, poor prices of cassava products and high labour cost fell in the category of 'severe' with mean scores of 3.17, 3.05 and 3.01 respectively. However, processing hazards, lack of market for cassava products, inadequate market information and impact of extension services with respective mean scores of 2.43, 2.48, 2.54 and 2.61 were considered 'not severe'. 
TABLE 2: Analysis of constraints using a 4-Point Likert type scale $(\mathrm{N}=160)$

\begin{tabular}{|c|c|c|c|c|c|c|c|c|}
\hline Constraints & $\begin{array}{c}4 \\
\text { Very } \\
\text { severe }\end{array}$ & $\begin{array}{c}3 \\
\text { Severe }\end{array}$ & $\begin{array}{c}2 \\
\text { Not } \\
\text { severe }\end{array}$ & $\begin{array}{c}1 \\
\text { In- } \\
\text { different }\end{array}$ & $\Sigma$ & Rank & $\bar{X}$ & Remark \\
\hline $\begin{array}{l}\text { Lack of mkt. } \\
\text { for cass. Prodts. }\end{array}$ & $\begin{array}{c}30 \\
(18.8)\end{array}$ & $\begin{array}{c}31 \\
(19.40)\end{array}$ & $\begin{array}{c}84 \\
(52.5)\end{array}$ & $15(9.4)$ & 396 & 9 & 2.48 & $\begin{array}{c}\text { not } \\
\text { severe }\end{array}$ \\
\hline $\begin{array}{l}\text { Poor prices of } \\
\text { Cass. Prodts. }\end{array}$ & $\begin{array}{c}79 \\
(49.4)\end{array}$ & $\begin{array}{c}35 \\
(21.9)\end{array}$ & $\begin{array}{c}25 \\
(15.6)\end{array}$ & $\begin{array}{c}21 \\
(13.1)\end{array}$ & 492 & 5 & 3.05 & Severe \\
\hline $\begin{array}{l}\text { High cost of } \\
\text { Process eqpt. }\end{array}$ & $\begin{array}{c}88 \\
(55.0)\end{array}$ & $\begin{array}{c}42 \\
(26.3)\end{array}$ & $\begin{array}{c}29 \\
(18.1)\end{array}$ & $\begin{array}{c}1 \\
(0.6)\end{array}$ & 537 & 2 & 3.35 & Severe \\
\hline $\begin{array}{l}\text { High transpt. } \\
\text { Cost. }\end{array}$ & $\begin{array}{c}58 \\
(36.3)\end{array}$ & $\begin{array}{c}72 \\
(45.0)\end{array}$ & $\begin{array}{c}29 \\
(18.1)\end{array}$ & $1(0.6)$ & 507 & 4 & 3.17 & Severe \\
\hline $\begin{array}{l}\text { Inadequate } \\
\text { Mkt.Informtn }\end{array}$ & $\begin{array}{c}31 \\
(19.4)\end{array}$ & $\begin{array}{c}43 \\
(26.9)\end{array}$ & $\begin{array}{c}67 \\
(41.9)\end{array}$ & 19 (11.9) & 406 & 8 & 2.54 & $\begin{array}{c}\text { not } \\
\text { severe }\end{array}$ \\
\hline $\begin{array}{l}\text { Less Impact of } \\
\text { Exten. Servcs. }\end{array}$ & $\begin{array}{c}33 \\
(20.6)\end{array}$ & $\begin{array}{c}43 \\
(26.9)\end{array}$ & $\begin{array}{c}73 \\
(45.6)\end{array}$ & $\begin{array}{c}11 \\
(6.9)\end{array}$ & 418 & 7 & 2.61 & $\begin{array}{c}\text { not } \\
\text { severe }\end{array}$ \\
\hline $\begin{array}{l}\text { Processing } \\
\text { Hazards }\end{array}$ & $\begin{array}{c}18 \\
(11.2)\end{array}$ & $\begin{array}{c}52 \\
(32.5)\end{array}$ & $\begin{array}{c}71 \\
(44.4)\end{array}$ & $19(11.9)$ & 389 & 10 & 2.43 & $\begin{array}{c}\text { not } \\
\text { severe }\end{array}$ \\
\hline Lack of Funds & $\begin{array}{c}91 \\
(56.9)\end{array}$ & $\begin{array}{c}49 \\
(30.6)\end{array}$ & $\begin{array}{c}19 \\
(11.9)\end{array}$ & $\begin{array}{c}1 \\
(0.6)\end{array}$ & 550 & 1 & 3.44 & Severe \\
\hline $\begin{array}{l}\text { High Labour } \\
\text { Cost }\end{array}$ & $\begin{array}{c}46 \\
(28.8)\end{array}$ & $\begin{array}{c}71 \\
(44.4)\end{array}$ & $\begin{array}{c}41 \\
(25.6)\end{array}$ & $\begin{array}{c}2 \\
(1.2)\end{array}$ & 481 & 6 & 3.01 & Severe \\
\hline $\begin{array}{l}\text { Cassava } \\
\text { Tuber's } \\
\text { Scarcity }\end{array}$ & $\begin{array}{c}78 \\
(48.8)\end{array}$ & $\begin{array}{c}49 \\
(30.6)\end{array}$ & $\begin{array}{c}31 \\
(19.4)\end{array}$ & $\begin{array}{c}2 \\
(1.2)\end{array}$ & 523 & 3 & 3.23 & Severe \\
\hline
\end{tabular}

Source: Field Survey 2009. Parentheses are in percentages

The response as regards impact of extension services in Table 2 poses a surprise, as extension: farmer's ratio in Nigeria is noted to be as high as 1:2,500 
(llevbaoje, 2004). Perhaps, the processors may have underestimated the importance of extension in increasing their productivity. A similar reason could be adduced for their response regarding processing hazards, which is in contrast with the findings of Fejemilehin and Hinadu (1995), where they stated that occupational and health hazards associated with cassava processing could be enormous.

\section{Relationship between socio-economic characteristics and constraints}

Table 3 shows the relationship between selected socio-economic characteristics and the constraints to cassava processing. The chi-square test of independence revealed that socio-economic characteristics such as gender, educational status, marital status, membership of cooperative society, age of processor and experience in cassava processing were all significant at $5 \%$ level of significance. It implies that all these characteristics determine the intensity of the constraints to cassava processing in the study area. For instance, on gender, a male respondent views constraints to cassava processing differently from his female counterpart. Similarly, what is seen as a constraint to a processor with 2 year experience may not be a constraint to a person with 10 or more years of experience. However, product category was not significant and therefore independent of constraints to cassava processing in the study area. This implies that regardless of what the respondent produces, constraints in one form or the other is a general experience to all. 
TABLE 3: Relationship between selected socio-economic characteristics and constraints

\begin{tabular}{|c|c|c|c|c|}
\hline Variable & Calculated X2 & Tabulated X2 & $\begin{array}{c}\text { Degrees of } \\
\text { freedom }\end{array}$ & Decision \\
\hline Gender & 23.40 & 7.81 & 3 & Significant \\
\hline $\begin{array}{l}\text { Educational } \\
\text { status }\end{array}$ & 113.59 & 25.00 & 15 & Significant \\
\hline Marital stat. & 15.68 & 12.60 & 6 & Significant \\
\hline Co'op. society & 1.370 & 16.00 & 9 & Significant \\
\hline Product category & 59.21 & 16.90 & 9 & $\begin{array}{l}\text { Not } \\
\text { significant }\end{array}$ \\
\hline Age & 46.21 & 25.00 & 15 & Significant \\
\hline Years of exp. & 32.67 & 28.90 & 18 & Significant \\
\hline
\end{tabular}

Source: Output from SPSS16

\section{CONCLUSION AND RECOMMENDATIONS}

The study revealed that value addition to cassava provided a means of livelihood to farmers in the state. The activity is undertaken mostly by women and the level of illiteracy is high, with most processors funding processing activities from their personal savings. Several constraints militate against cassava processing in the state, with the very severe ones as lack of funds, high cost of processing and scarcity of cassava tubers. There exists a significant relationship between constraints to cassava processing and socio-economic characteristics of farmers like gender, educational status, marital status, membership of cooperative society, age and processing experience.

Based on the findings of this study, the following measures are recommended:

- Government should make massive investment in subsidizing cassava processing equipment in order to encourage diversification of 
processing options in the downstream sector;

- To leverage and enhance cassava processing activities, Government should put in place deliberate fiscal policy to lower interest rate, and reduce complex procedure/stringent conditionalities for accessing microcredit. In this regard, Government should hasten to disburse the 50 billion Naira under the micro-finance fund;

- To stabilize product prices and sustain production, Government should put in place a buy-back policy programme for processed cassava products.

\section{REFERENCES}

Ayoade, A.R. and R.G. Adeola (2009). Constraints to domestic utilization of cassava in Osun State, Nigeria; Ozean Journal of Social Sciences 2(2), 83-87. Ozean Publication.

Fajemilehin, B.R. and M.K. Jinadu (1995). Occupational health hazards associated with traditional methods of cassava processing in Nigeria. African Newsletter, February 38-39.

Food and Agriculture Organization of the United Nations (2002). A cassava industrial revolution in Nigeria. FAO corporate document depository.

Food and Agriculture Organization of the United Nations (FAO) (2003). Championing the cause of cassava; News \& highlights.

Food and Agriculture Organization of the United Nations (2009). Cassava production for countries by Commodities; Food and agricultural commodities production. www.faostat.fao.org Retrieved on 05/03/2011

Ikpi, A.E., and N.D Hahns, eds (1989). Cassava: lifeline for the rural households. Lagos, Nigeria UNICEF.

llevbaoje, E.I (2004). Training and visit extension system flourishes in Nigeria. Berater Innen News 1;9

Kwara State Agricultural Development Project (KWADP). 2008 Annual Report.

Ngoddy,P.O (1977). Determinants of the development of technology for processing roots and tubers in Nigeria. Proceedings of the First National Seminar on Root and Tuber Crops. Umudike Nigeria NRCRI.

Nweke, I.F., Spencer, D.S.C and Lyman, K.J (2002). The cassava transformation: Africa's best-kept secret. Michigan State University Press, East Lansing.

Oderemi, K. and D. Awoyinfa (2009). Policy reversal: N20bn investment under threat. The PUNCH. Sunday edition, November 30, 2011: 8.

O' Hair, K. Stephen (2000). Cassava: new crop fact sheet, Tropical Research and Education Centre, University of Florida. 
Okigbo, N. Bede 1980: Nutritional implications of projects giving high priority to the production of staples of low nutritive quality. The case of cassava in the humid tropics of West Africa. Food and Nutrition Bulletin, United Nations University, Tokyo, 2 (4): 1-10.

Olakulehin, J.O and Ajijola, F.S (2005). Cassava production: Nigeria's best kept secret. Lagos Farmer 1, 1-4.

Onabolu,A. (2001) Cassava processing, consumption and dietary cyanide exposure. Ph.D diss. Karolinska Institute Sweden.

Spencer, D.S.C (1976). African women in agricultural development: a case study of Sierra Leone. American overseas liaison committee paper No. 9, Washington D.C. 